JELENA ANĐELKOVIĆ GRAŠAR

Institute of Archaeology

Belgrade, Serbia

E-mail: jelenandjelkovic@gmail.com

MLADEN MLADENOVIĆ

Laboratory for Bioarchaeology

Department of Archaeology, Faculty of

Philosophy, University of Belgrade

Belgrade, Serbia
Received: November $15^{\text {th }} 2021$

Accepted: November $20^{\text {th }} 2021$

Original research article

902:37(497.4)"2021"

COBISS.SR-ID 55205897

https://doi.org/10.18485/arhe_apn.2021.17.8

ANA GAVRILOVIĆ, DANICA GRUJIĆ, PREDRAG ĐERKOVIĆ, PEĐA PERIĆ, IVAN ILIĆ

The archaeological student club, Faculty of

Philosophy, University of Belgrade

Belgrade, Serbia

\title{
ARCHAEOLOGY WORKSHOPS AS AN EDUCATIONAL APPROACH IN COMMUNICATION WITH THE PUBLIC - CASE STUDY ROMAN GAMES IN PTUJ
}

\begin{abstract}
The Roman Festival in Ptuj aims to connect the local community and visitors with the Roman heritage and present a part of Roman life that includes the army, gladiatorial fights, conflicts with the Barbarians, traditional Roman food, craftsmen, etc. Within the project "Sadike na prihodnost" supported by the Erasmus + programme, some educational activities were organised during the event. This was a good opportunity for the creation of specific and thematically defined archaeological workshops, which were used as a good educational approach in communication between professionals and the wider public. Visitors were also able to get acquainted with the skills required for the slingshot used by Roman soldiers, through a practical workshop that students prepared. In such a way it can be said that the project results contributed to a widening educational approach towards the Ptuj public and the local community.
\end{abstract}

KEYWORDS: ARCHAEOLOGY WORKSHOPS, EDUCATION, METHODOLOGY, TOOLS, PUBLIC ARCHAEOLOGY.

\section{INTRODUCTION}

In 2021, the Roman Games Festival in Ptuj, (Slovenia) were organised for the 14th time. In its history the festival has become renowned for various re-enactment shows, experimental archaeology and living history approaches. Most of all the Festival is the best known for the wide participation of the local community.

Within the project "Sadike na prihodnost", co-funded by the European Commission's ERAS-
MUS+ programme, partners Society for Roman History and Culture (Društvo na rimsko zgodovino in kulturo Ptuj) and the Institute of Archaeology collaborated in the educational programme development and workshop design. The Institute of Archaeology provided scientific support to the project and invited students of archaeology to join the project in order to implement workshops. The long term collaboration between the Institute and the Archaeological student club from the Faculty of Philosophy again gave results. Among others, 
the tasks of these workshops were to educate visitors in an interesting way from the archaeological perspective about the findings related to the Roman period and their significance in creating a story about the past. Visitors were also able to get acquainted with the skills required for the slingshot used by Roman soldiers, through a practical workshop that students prepared.

\section{THE THEORETICAL AND METHODOLOGICAL FRAMEWORK FOR AN EDUCATIONAL APPROACH IN THE POPULARISATION OF ARCHAEOLOGY}

The term public archaeology or archaeology for the public was used for the first time in 1972, in McGimsey's publication Public Archaeology. The very meaning of the term has changed over the years, depending on the needs of the scientific society at any particular time. In the beginning, this term was defined as a practice within the management of cultural heritage. The initial interest in the audience stemmed from the fact that it was understood that the unprofessional public could help provide the needs for the adequate protection and preservation of archaeological heritage (McGimsey 1972).

In the preface of the Public Archaeology Journal, public archaeology is defined as an independent discipline. The author himself, Neal Acherson, suggests that public archaeology deals with the problems that arose from the transition of archaeology to the real world of economic conflicts and political struggle. He also concludes that this area addresses the issue of professional ethics. In the second part of the preface, Acherson states that the domain of public archaeology includes topics related to illegal trade, illegal excavations, privatisation of archaeology, human rights in archaeology, and the representation of archaeology in fiction, film, television and other media (Acherson 2000: 2). Even though the discussion about public archaeology started over two decades ago, we are still battling with more or less the same issues. The sudden rise in a general disbelief in science together with the active (ab)use of the internet in the general public resulted in a lot of pseudoscientific (to be more precise pseudoarchaeology) narratives and adapting our approach of outreach to the general public can be a potential solution for overcoming or reducing that problem.

In addition to the fact that the meaning and comprehension of this term has changed over the years, we can say that different authors have defined and divided this term differently, depending on the way they understood the term, but also depending on the needs of their work. We will give examples of several authors. McManamon defined public archaeology as "the management of the national archaeological heritage in the public interest" as an academic discipline (Simpson and Williams 2008: 72). Gabriel Moshenska, who in the practice of public archaeology distinguishes several categories, also gave the definition of the archaeological education matrix that we used in this paper. He singled out archaeology for the public, archaeology with the public, archaeology conducted by the public and archaeological education on the basis of the manner of public engagement and on the basis of aspects of the discipline (Moshenska 2017: 9-10).

Finally, any research conducted by specialised institutions and individuals within them takes place and is evaluated within the research community itself, but also outside it.

While it is only natural to present our work to the members of our professional community, it should be no different when talking about presenting our work to the general public. Many results of scientific work become part of everyday life and those members of society who know nothing about the principles on which they are based will more or less consciously use the ultimate outcomes of this specialised knowledge. Archaeology, according to a large number of researchers such as Tilley Christopher (1989), has its full meaning only when the results of our research become publicly available.

Archaeological ethnography was used as a methodological framework for the process of engaging with the community and while writing this paper. In using this methodology, we agree with Zager and Pluckhahn, who argue that archaeologists have increasingly turned to ethnography as a tool for understanding the contemporary social context of material culture, archaeological practice... (Zager and Pluckhahn 2013: 48). Using eth- 
nography along with storytelling, which has both didactic and reflexive benefits and is valuable for both its creators and their audience, we achieved outstanding outreach results. Archaeological storytelling is the creation of prose, poetry, performance, song or other modes by an archaeologist that incorporates archaeological data, has a narrative structure, and transcends standard archaeological presentation, as Praetzellis would describe it (Praetzellis 2014: 5135). This relationship between the archaeology (with or without a developed storytelling methodology) and the public is exactly among the four basic aims of archaeology as practiced: to learn about the past, to learn from the past, to manage the heritage of the past and to enable public engagement with the past (Henson 2017:45).

The key is to illustrate how a more dynamic environment for knowledge exchange, like themed festivals, can be more effective than some traditional (and mostly institutionalised) ways of establishing communication between academic knowledge and the general public (like museums, exhibitions and panel discussions). The ambience and dynamism of festivals motivate people to participate in previously designed activities that, in our case, were accomplished with a storytelling approach and were aimed at the popularisation of archaeology, encouraging discussion, and the sharing of knowledge about different aspects of this complex scientific field (Chipangura, Nyamashosho and Pasipanodya 2019: 16)

\section{WORKSHOPS}

Workshops within the project "Sadike na prihodnost" were designed, developed and conducted by the Institute of Archaeology and the Archaeological student club from the Faculty of Philosophy, with participation of students from different class levels (Bachelor through to $\mathrm{PhD}$ programme). Workshops were thematically divided between those with a more educational purpose and those that were oriented towards the general audience and the popularisation of archaeology as a science. Mladen Mladenović, Danica Grujić, Predrag Đerković, Mirjana Đorđević, Peđa Perić and Ivan Ilić participated in the first group of workshops.
Animal bones speak out! (Developed and led by Mladen Mladenović and Danica Grujić)

The main purpose of the archaeozoological workshop "Animal bones speak out" was to introduce the results of archaeofaunal analyses from archaeological sites in the territory of present-day Serbia to the scientific community and the general public in Ptuj. The workshop was designed in such a way that the introductory part was focused on the importance of archeozoological research, as well as on the methods archaeologists use to obtain data to reconstruct human-animal relationships in the past (e.g. Driesch 1976; Reitz, Wing 2008; Schmid 1972; Wilson et al. 1982). The next step of the workshop was to demonstrate which information can be gathered from animal remains, such as paleoenvironmental reconstructions, the diversity of animal species that occupied the region in the past, dietary patterns, and different economic aspects of human societies through time (Reitz, Wing 2008; Rusell 2011). Students have talked about the results of the archaeozoological analyses from the Early Palaeolithic (Dimitrijević 1996) to the Late Medieval period sites (Mladenović, Mladenović 2020), but in the spirit of the festival, the focus was on the Roman period (Marković 2018; Младеновић 2020; Vuković 2020). One of the fun facts about Roman dietary habits that was discussed is that in times of need they practiced consumption of equid and camel meat, which is suggested by the butchering marks inflicted by the metal butchering tools on bones of the indicated species (Marković 2018; Mladenović 2021; Vuković, Bogdanović 2013) (Fig. 1). Communicating with the audience through picture/video materials and motivating them to think critically and through a set of questions and answers (from both sides), are methods that have been included in the process of unravelling this piece of the past.

Roman Coinage: Pecunia non olet! (Developed and led by Peđa Perić)

For many years now, coins found on archaeological sites have been praised due to the high possibility of extracting valuable data from them. Not only are we able to date sites if we come across coins in certain contexts but we can also 


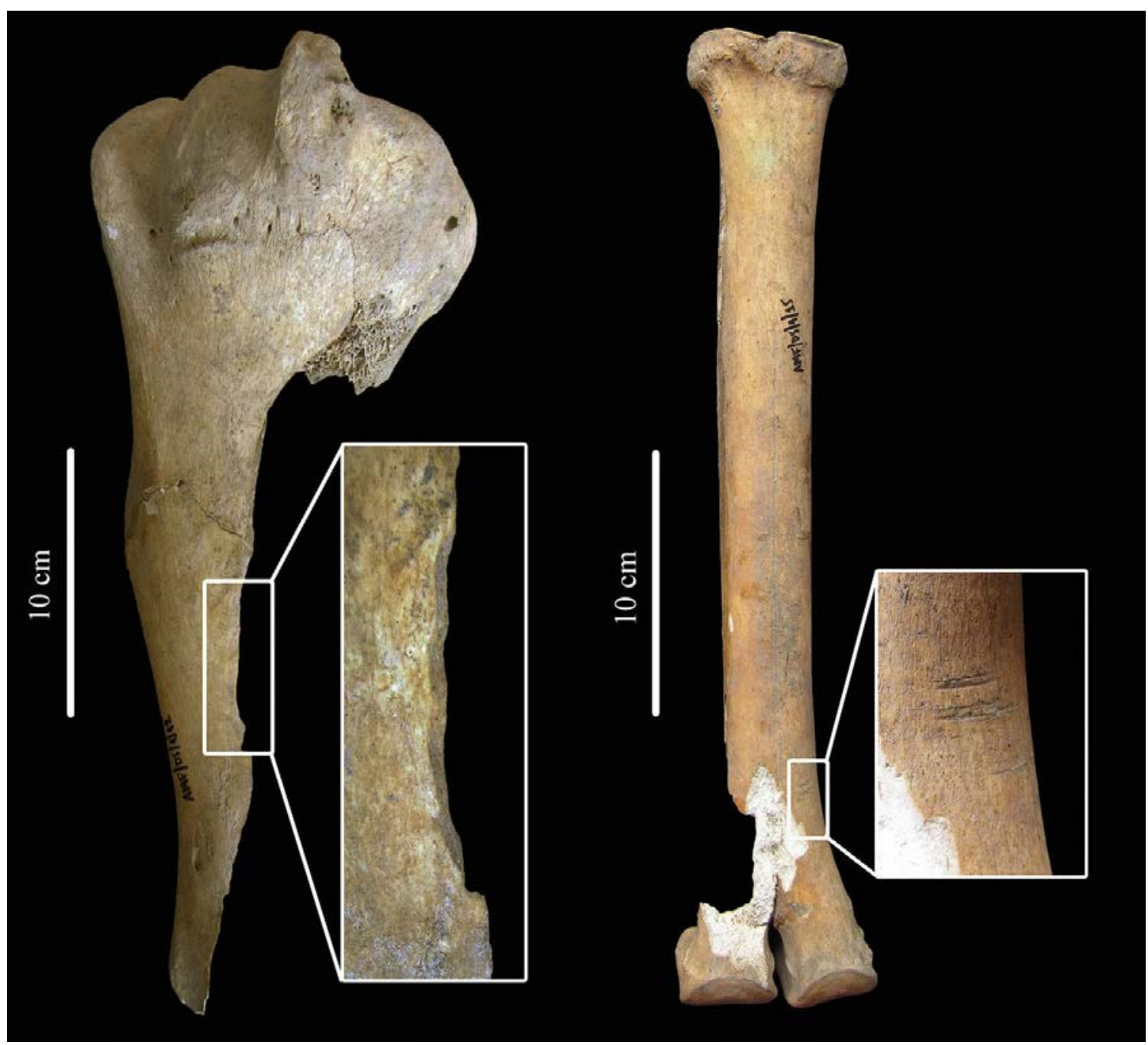

Fig. 1 -- Proximal Humerus (caudolateral view) and Metatarsal bone (anterior view) with the anthropogenic traces (Vuković, Bogdanović 2013).

expand our knowledge on cultural customs, the ways in which rulers issued propaganda material and even some events that happened in the past that are not well documented in written records (Мирковић 2014). Roman coinage is not an exception. As a matter of fact, all sorts of data extracted throughout the years serves as a prime example of how useful the careful analysis and interpretation of coins can be. The purpose of our numismatic presentation was to introduce the general public to a fascinating history and the major importance of Roman coinage. The workshop was aptly named pecunia non olet, considering that it is relevant both to coinage itself and to the fact that the Roman emperor Vespasian, who allegedly said the line when asked by his son Titus about public restroom taxation, was proclaimed emper- or by his legions in Ptuj (Suetonius, Vita Divi Vespasiani). Our story began with the earliest form of Roman proto-currency called aes rude. Essentially it was a non-standardised piece of bronze used for trading. A standardised form of Roman currency made of stamped bronze ingots known as aes signatum was also discussed, along with the first actual Roman coins, called aes grave (Burnett 1987; Crawford 1974). However, it is safe to say that our audience was most intrigued by republican and imperial coinage. Together, we explored various different types of coins and their value. Elaborate imperial iconography along with interesting reverse scenes depicting mighty gods, triumphant emperors and architectural wonders gave us an opportunity to incorporate many interesting stories about the Roman world, which 


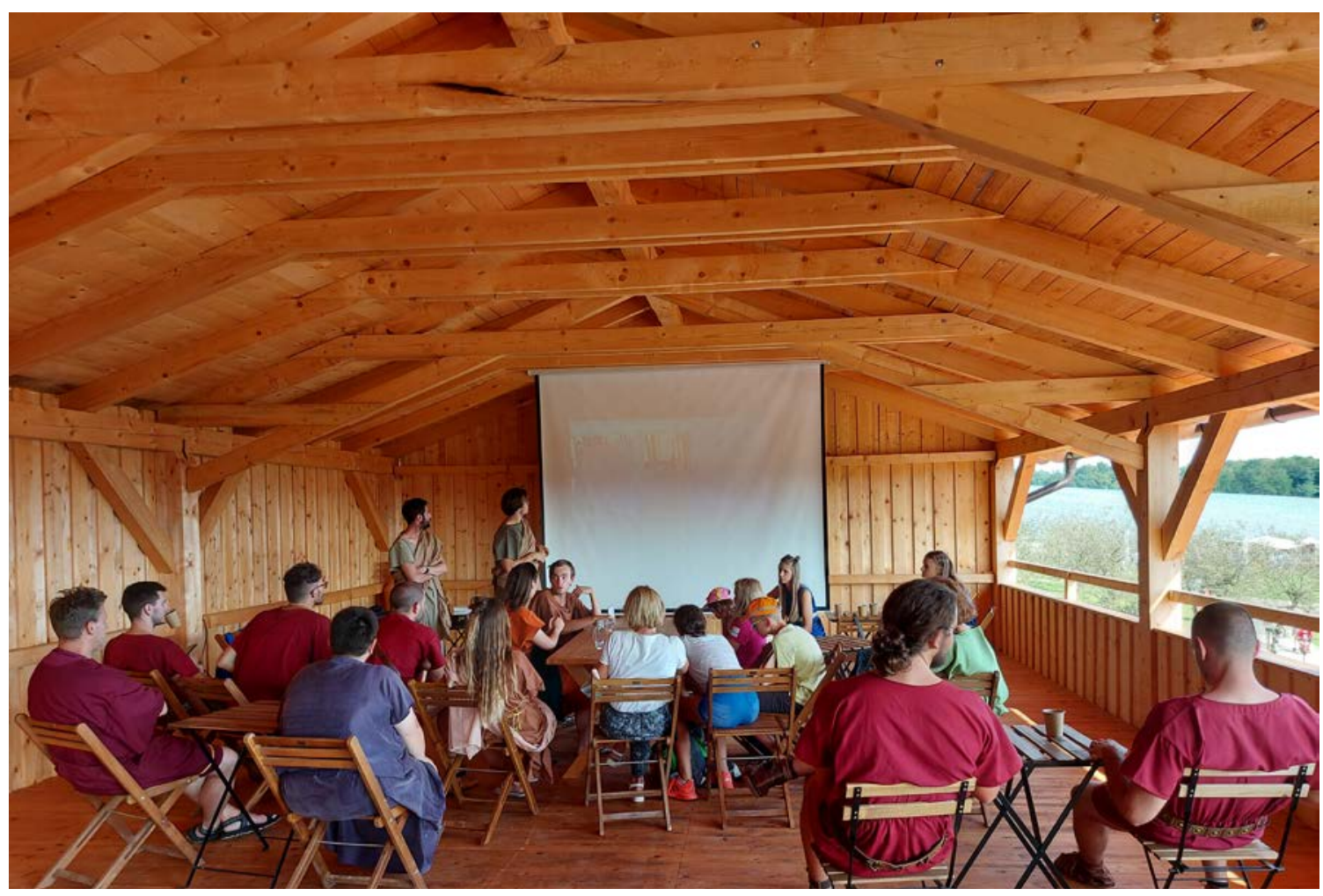

Fig 2. - Workshops and the audience.

gave an entertaining note to our workshop. Reading and understanding texts on imperial coins is of great importance, especially on the reverses. That is why we took a couple of comprehensible examples and had them translated by volunteers, with our assistance. All of them included a not so subtle political message aimed at Roman citizens. This illustrated how Roman emperors used coinage to spread messages of power, stability and hope throughout the vast empire, even though sometimes they were not supported by the status quo. Naturally, we could not miss a chance to talk about Roman mints in the territory of today's Serbia. Explaining abbreviations on Viminacium coinage along with the often unfortunate fates of the depicted emperors allowed us to talk about 3rd century Rome and the chaos that was raging at the time (Мирковић 2014). Our presentation ended with a story of coinage minted in the 4th century Sirmium, followed by a short introduction to monetary reforms executed by the emperors Aurelian, Diocletian and Constantine in order to fix late Roman currency. There is certainly much more than first meets the eye when it comes to the subject of ancient coins. This unique chance to indulge in a beautiful and well-planned festival and to hold an interactive numismatic presentation with an audience that truly enjoyed it as much as we did is exactly how communication between archaeologists and the public should be (Fig. 2).

Roman slings and slingers (Developed and executed by Ivan Ilić)

Ever since the Stone Age, slings were used all over the globe, both as hunting tools or weapons of war, and today they are used by experimental slingers in archaeological projects or for hobbies. The advantages of slings are that they are rather easy to make of simple materials and take a short amount of time to complete. Even if there are no proper projectiles, one could, for example use, any kind of stones found nearby.

Among Roman military troops, there were often slingers - either soldiers that had slings as their only weapon or those who carried slings as additional weapons. The soldiers who used slings as their only weapon were usually auxiliary troops. The best slingers were considered to come 


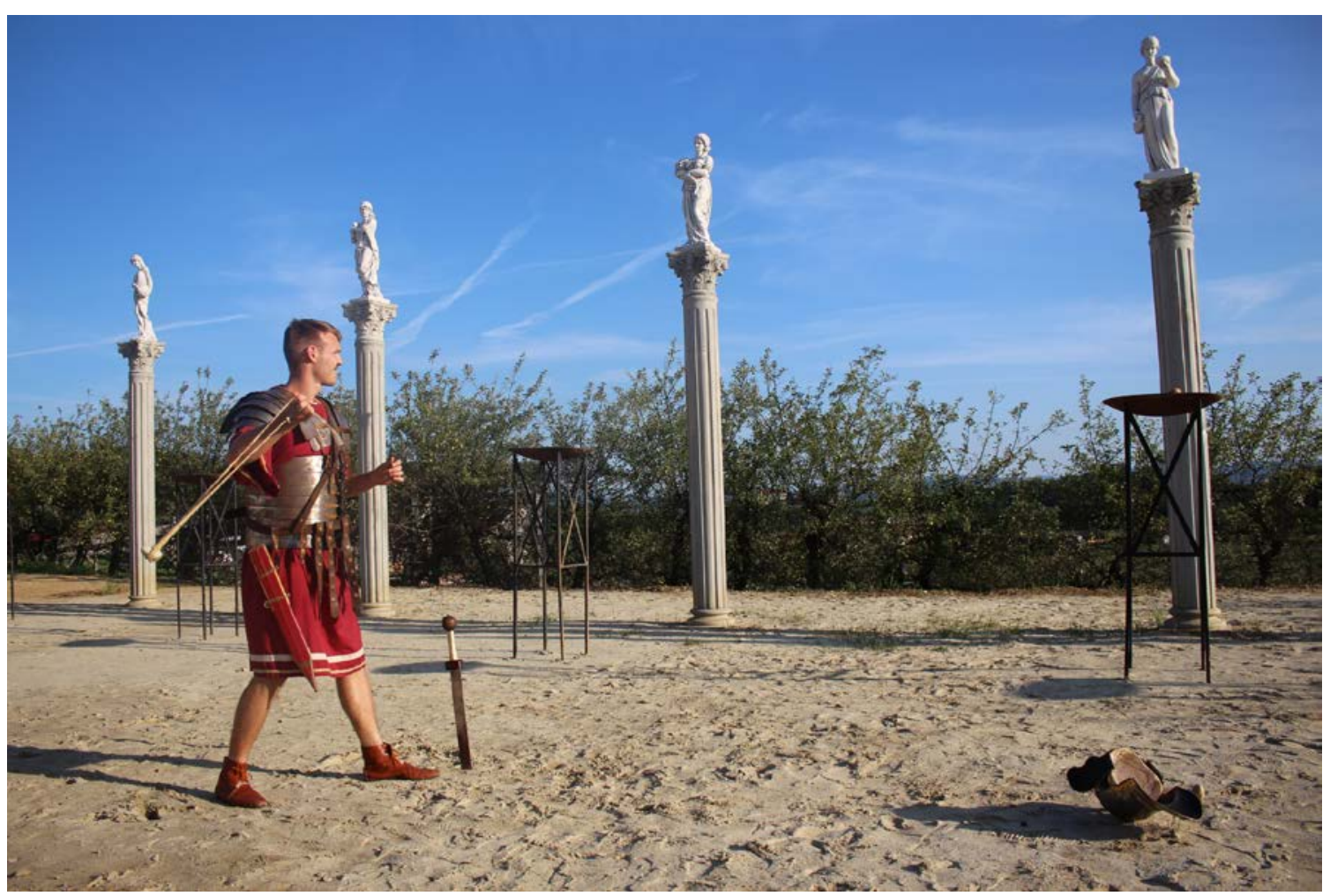

Fig. 3 -Demonstration of slingshot skill.

from the Balearic Islands in modern Spain (Titus Livius "Ab urbe condita", The History of Rome, book 21, chapter 21).

It is believed that they were trained to use slings from the youngest age. It is also believed that Balearic mothers did not give their children food until they had shot bowls with their meals in them. Skilled slingers were said to be able to hit targets at a distance of up to $300 \mathrm{~m}$.

The focus of this workshop was to theoretically and physically introduce the Roman slinging tradition to people who have never seen slinging before (Fig. 3). Visitors of this festival were given an opportunity to try making (braiding) their own slings, with assistance. The most exciting thing was teaching others how to use the sling. Although proper projectiles are made of stones, clay or lead, people who tried slinging during the Roman festival in Ptuj used tennis balls instead. This workshop was one of many ways we made strong connections with other participants, which resulted in a two-way exchange of knowledge. One particularly special event was a demonstration of a sling's reach and precision in hands of a skilled slinger who, during ancient times, fought on the Roman side.
Recognising mystery artefacts (Developed and led by Predrag Đerković)

Items of everyday use often attract the attention of visitors of museums and archaeological sites, something that especially applies to those artefacts that are similar to modern-day objects. It has often been noted that the general public is amazed by the idea that Romans used similar combs or jewellery to those we use today. That is why it was decided to amaze the audience from Ptuj in the same way.

This workshop consisted of several dozen photos, which were shown to the spectators. Starting from metal urns and ending with Roman fences, all the images were of unique artefacts found in modern-day Serbia. After seeing a photo of each object, visitors were asked to think about the purpose of the object, its dating and its meaning. After the initial minute of thinking, the spectators were encouraged to start a discussion among themselves regarding the purpose of the shown object. The final stage of the work consisted of the archaeologist's explanation of the image. 


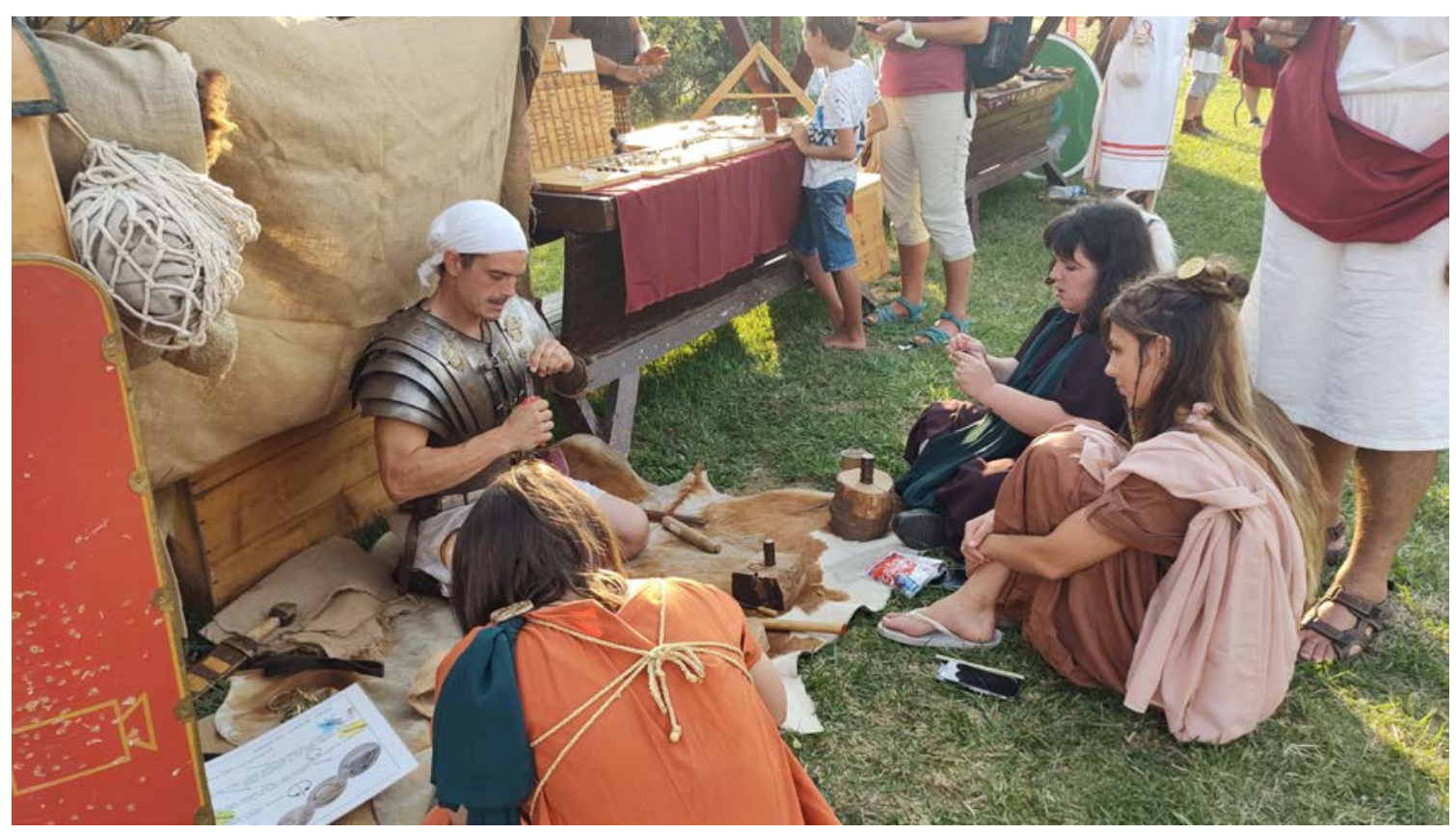

Fig. 4 - Students participating the fibulae making workshop.

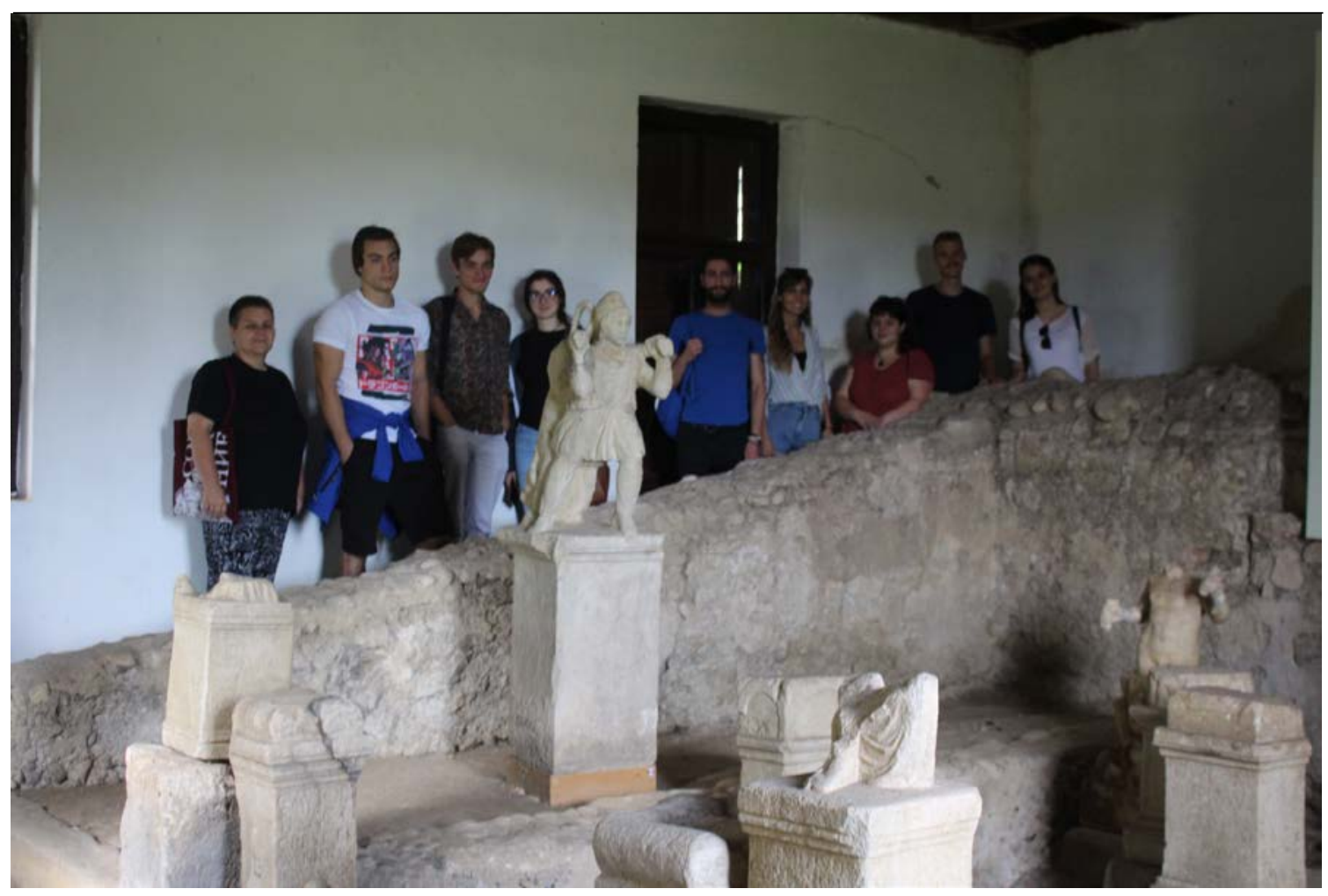

Fig. 5 - Students in Museums’ visits.

The students learned something new too!

In addition to the workshops, one of the most interesting things in the camp was a workshop on making fibulae, organised by the Vespasian Cultural Association, from Ljubljana. The students were introduced to the appearance of different types of fibulae characteristic of the Roman pe- 
riod and to the way in which omega fibulae were made (Fig. 4). The whole process of making requires patience and time, especially for beginners, but, in the end, it was worth it because the students took with them a beautiful souvenir that was made by themselves. During this workshop, the students also learned a lot of interesting information about fibulae, as well as about the work of the Vespasian Cultural Association and their activities.

In the camp, the students also had the opportunity to get acquainted, for example, with the method of making flutes, Roman instruments and music, as well as with various societies that presented their traditionally made products. They were also introduced to the cultural heritage of Ptuj by visiting sites and through the presentation of the local museum, which took place in the vicinity of the camp (Fig. 5).

While returning home, another stop was made, again aimed at enhancing the experience of the students and enriching their education (both archaeological and museological), at Krapina Museum (Croatia). Besides learning about Krapina Neanderthals, students were able to enjoy the modern and interactive exhibition dedicated to evolution.

\section{CONCLUSION}

Workshops conducted during the Roman Games in Ptuj confirmed an already known fact - archaeology is necessary in education. Archaeological knowledge is important, not only in formal education, but for non-formal ways of teaching young people and adults who are not necessarily intending to become archaeologists. In such a way, archaeology can be considered a bridging discipline between the past and present - archaeology can give people the knowledge and skills of archaeological practice, and help them to make links between the past and present and to see the value and complexity of heritage (Henson 2017: 43-45).

Most of the people who attended the workshop were younger than 18 and, although the initial expectations of our team were not big, they showed an unexpected knowledge about everyday life in the Balkan provinces of the Roman empire. While some of the participants actually knew the right answers, which was quite surprising considering their young age, others were completely involved in collective brainstorming. This led to them arriving at some interesting conclusions. It is also notable that around 15 visitors were present at the beginning, while the number at the end increased to around 50, with a group from Split also joining. The fact that none of the participants left the workshop before its very end is a positive result on its own, showing that this kind of interactive approach to presenting archaeological heritage can be found to be more than interesting in promoting the Roman past.

Unfortunately, it was only possible to show photos on a big screen, rather than presenting the actual artefacts from Viminacium as well as other Roman sites in Serbia. However, this can be a good starting point for some of the upcoming workshops, since it is generally noted that the public can relate to actual artefacts even better than images.

At this point, it is abundantly clear that the described workshops showed positive results and that this model could be useful at any occasion similar to the Roman festival in Ptuj. Finally, this kind of initiative has already been recognised by another Erasmus + project, TRAME (Tracce di memoria 2020-1-IT02-KA201-079794), in which best practices of non-formal and practical learning are presented, as well as an innovative methodological approach to cultural heritage as a basis in the educational process for youth (Анђелковић Грашар 2021: 85; Nochita 2021: 180-185).

\section{BIBLIOGRAPHY}

\section{Sources:}

Suetonius: The Lives of the Twelve Caesars; An English Translation, Augmented with the Biographies of Contemporary Statesmen, Orators, Poets, and Other Associates. Gebbie \& Co. 1889.

Titus Livius „Ab urbe condita“ (The History of Rome, book 21, chapter 21).

\section{Literature:}

Acherson, N. 2000

Editorial, Public Archaeology Journal, 1:1-4. 


\section{Анђелковић Грашар, J. 2021}

Интерпретација културног наслеђа и формално образовање: 'TRAME" Еразмус+ пројекат као пример добре праксе, Српско археолошко друштво XLIV скупштина и годишњи скуп, Параћин, 14. - 16. октобар 2021. године Програм, извештаји и апстракти, Параћин 2021, 98 (Anđelković Grašar, J. 2021

Interpretacija kulturnog nasleđa i formalno obrazovanje: "TRAME" Erazmus + projekat kao primer dobre prakse, Srpsko arheološko društvo XLIV skupština i godišnji skup, Paraćin, 14.-16. oktobar 2021. godine Program, izveštaji i apstrakti, Paraćin 2021, 98).

Burnett, A. 1987

Coinage in the Roman World. Numismatic Fine Arts Intl.

\section{Dimitrijević, V. 1996}

Upper Pleistocene mammals from cave deposits in Serbia, Acta zoologica cracoviensia 39 (1): 117-120.

\section{Driesch, A. 1976}

A guide to the measurement of animal bones from archaeological sites, Cambridge: Peabody Museum at Harvard University.

\section{Henson, D., 2017}

Archaeology and Education, in: Key Concepts in Public Archaeology, edited by Gabriel Moshenska, 1-13. London: University College London Press, 43-59.

\section{Marković, N. 2018}

Ekonomija ranovizantijske metropole Caričin grad: arheozoološki pristup, nepublikovana doktorska disertacija, Beograd: Filozofski fakultet, Univerzitet u Beogradu.

\section{McGimsey, C. R. 1972}

Public Archaeology, Seminar Press, New York London.

\section{Metcalf, William E. 2012}

The Oxford Handbook of Greek and Roman Coinage. New York: Oxford University Press.
Michael H. Crawford 1974

Roman Republican Coinage. Cambridge University Press.

\section{Мирковић, М. 2014}

Историја Римске Државе, Београд: Службени гласник.

(Mirković, M. 2014

Istorija Rimske Države, Beograd: Službeni glasnik).

\section{Младеновић, М. 2020}

Исхрана становника утврђене палате Felix Romuliana - Гамзиград током касноантичког и рановизантијског периода: остаци животиња из куле 15, мастер теза, Београд: Филозофски факултет, Универзитет у Београду.

(Mladenović, M. 2020

Ishrana stanovnika utvrđene palate Felix Romuliana - Gamzigrad tokom kasnoantičkog i ranovizantijskog perioda: ostaci životinja iz kule 15, master teza, Beograd: Filozofski fakultet, Univerzitet u Beogradu).

\section{Mladenović, M. 2021}

Exploitation of beast of burden in the territory of present-day Serbia during the Late Antique and the Early Byzantine periods: a zooarchaeological perspective, in: Marković, D., Mladenović, T. (eds.), 9th PZAF Book of Abstracts, Belgrade 2527 June 2021, 36.

\section{Mladenović, T., Mladenović, M. 2020}

Animal Exploitation in the Territory of Present-Day Serbia During the Medieval Period: a Zooarchaeological Perspective, in: Marković, N., Bulatović, J. (eds), Animal Husbandry and Hunting in Southeast Europe Through Time, 167-186, Oxford: Archaeopress Publishing Ltd.

Moshenska, G. 2017

Introduction: Public Archaeology as Practice and Scholarship Where Archaeology Meets the World, in: Key Concepts in Public Archaeology, (ed.) Gabriel Moshenska, London: University College London Press, 1-13.

\section{Nocita, M. 2021}

TRAME antiche e moderne per un nuovo tessuto europeo, in: Roma vocazione all'accoglienza e 
senso di comunita dalla storia al contamporaneo, Chiarilli, G. (ed.), Roma: Palombi editori.

Rakestraw, T., Reynolds, A. 2001

Archaeology and the Public: Exploring Popular Misconceptions, Inquiry: The University of Arkansas Undergraduate Research Journal: 2(1): 25-29. Reitz, E., Wing, E. 2008

Zooarchaeology (2nd edition), Cambridge: Cambridge University Press.

\section{Rusell, N. 2011}

Social Zooarchaeology Humans and Animals in Prehistory, Cambridge: Cambridge University Press.

Simpson, F. and Howards W. 2008

Evaluating Community Archaeology in the UK, Public Archaeology 7. 2: 69-90.

Schmid, E. 1972

Atlas of Animal Bones: for prehistorians, archaeologists and quaternary geologists, New York: Elsevier.

\section{Tilley, Ch. 1989}

Archaeology as socio-political action in the present, Critical traditions in contemporary archaeology, V. Pinsky, A. Wylie (eds.), Cambridge, 104-116.

Tušek, I. 2019

Rimska Vojska v Republiki in Cesarstvu ter Rimski Vojaški Nagrobniki iz Petovione, Zgodovinsko društvo "Poetovio 69", Ptuj.

Vuković, S., Bogdanović, I. 2013

A Camel Skeleton from the Viminacium Amphitheatre, Starinar 63: 251-267.

Vuković, S. 2020

Animal Husbandry and Hunting in Roman Provinces in Serbia: a Zooarchaeological Overview, in: Marković, N., Bulatović, J. (eds.), Animal Husbandry and Hunting in Southeast Europe Through Time, Oxford: Archaeopress Publishing Ltd, 130-142.

Wilson, B., Grigson, C., Payne, S. (eds.) 1982 Aging and Sexing Animal Bones from Archaeological Sites, Oxford: Bar Publishing.
Zager, R.K., Pluckhahn, T.J. 2013

Assessing Methodologies in Archaeological Ethnography: a Case for Incorporating Ethnographic Training in Graduate Archaeology Curricula, Public Archaeology 12 (1): 48-63.

\section{Links:}

http://viminacium.org.rs/arheoloski-park/programi-za-decu/edukativne-drustvene-igre/

http://viminacium.org.rs/arheoloski-park/programi-za-decu/

\section{REZIME \\ ARHEOLOŠKE RADIONICE KAO EDUKATIVNI PRISTUP U KOMUNIKACIJI SA JAVNOŠĆU - PRIMER RIMSKE IGRE U PTUJU}

\section{KLJUČNE REČI: ARHEOLOŠKE RADIONICE, EDUKACIJA, METODOLOGIJA, ALATI, JAVNA ARHEOLOGIJA.}

Rimski festival u Ptuju ima za cilj da poveže lokalnu zajednicu i posetioce sa rimskim nasleđem i predstavi deo rimskog života koji uključuje vojsku, gladijatorske borbe, tehnike ratovanja, tradicionalnu rimsku hranu, zanatstvo itd. U okviru projekta „Sadike na prihodnost” uz podršku Erazmus + programa neke od edukativnih aktivnosti organizovane su tokom događaja. Ovo je bila dobra prilika za kreiranje specifičnih i tematski definisanih arheoloških radionica, koje su korišćene kao dobar edukativni pristup u komunikaciji između stručne i šire javnosti. Posetioci su takođe mogli da se upoznaju sa veštinom gađanja iz praćke koju su koristili rimski vojnici kroz praktičnu radionicu koju su studenti pripremili. Na taj način se može reći da su rezultati projekta doprineli širenju edukativnog pristupa prema ptujskoj javnosti i lokalnoj zajednici. Radionice u okviru projekta "Sadike na prihodnost“ iz Erazmus + programa sufinansiranog od strane Evropske Komisije osmislili su, razvili i sproveli Arheološki institut i Klub studenata Arheologije Filozofskog fakulteta Univerziteta u Beogradu. Radionice su tematski bile podeljene na edukativne i one koje su bile posvećene široj publici i popularizaciju arheologije kao nauke. 
Radionice održane tokom Rimskih igara u Ptuju potvrdile su već poznatu činjenicu - arheologija je neophodna u obrazovanju. Arheološka znanja su važna ne samo u formalnom obrazovanju, već i za neformalno učenje mladih i odraslih koji ne žele nužno da postanu arheolozi. Na taj način arheologija se može smatrati disciplinom koja povezuje prošlost i sadašnjost - arheologija može ljudima dati znanja i veštine arheološke prakse, i pomoći im da naprave veze između prošlosti i sadašnjosti, kao i uvid u vrednost i složenost nasleđa ( Henson 2017: 43-45).

\section{$* * *$}

Arheologija i prirodne nauke (Archaeology and Science) is an Open Access Journal. All articles can be downloaded free of charge and used in accordance with the licence Creative Commons - Attribution-NonCommercial-NoDerivs 3.0 Serbia (https://creativecommons.org/licenses/bync-nd/3.0/rs/.

Časopis Arheologija i prirodne nauke je dostupan u režimu otvorenog pristupa. Članci objavljeni u časopisu mogu se besplatno preuzeti sa sajta $i$ koristiti u skladu sa licencom Creative Commons - Autorstvo-Nekomercijalno-Bez prerada 3.0 Srbija (https://creativecommons.org/licenses/bync-nd/3.0/rs/. 